Article

\title{
Effects of Electrospinning on the Viability of Ten Species of Lactic Acid Bacteria in Poly(Ethylene Oxide) Nanofibers
}

\author{
Špela Zupančič $\left.{ }^{1,+}{ }^{(}\right)$, Katja Škrlec ${ }^{2,+}$, Petra Kocbek ${ }^{1}{ }^{(\mathbb{O}}$, Julijana Kristl ${ }^{1, *}$ and Aleš Berlec ${ }^{1,2, *}$ \\ 1 Faculty of Pharmacy, University of Ljubljana, Aškerčeva 7, SI-1000 Ljubljana, Slovenia; \\ spela.zupancic@ffa.uni-lj.si (Š.Z.); petra.kocbek@ffa.uni-lj.si (P.K.) \\ 2 Department of Biotechnology, Jožef Stefan Institute, Jamova 39, SI-1000 Ljubljana, Slovenia; \\ katja.luzarskrlec@gmail.com \\ * Correspondence: julijana.kristl@ffa.uni-lj.si (J.K.); ales.berlec@ijs.si (A.B.); Tel.: + 386-1-476-9500 (J.K.); \\ $+386-1-477-3754$ (A.B.) \\ + These authors contributed equally.
}

Received: 30 August 2019; Accepted: 15 September 2019; Published: 18 September 2019

\begin{abstract}
Lactic acid bacteria can have beneficial health effects and be used for the treatment of various diseases. However, there remains the challenge of encapsulating probiotics into delivery systems with a high viability and encapsulation efficacy. The electrospinning of bacteria is a novel and little-studied method, and further investigation of its promising potential is needed. Here, the morphology, zeta potential, hydrophobicity, average cell mass, and growth characteristics of nine different species of Lactobacillus and one of Lactococcus are characterized. The electrospinning of polymer solutions containing $\sim 10$ log colony forming units (CFU)/mL lactic acid bacteria enabled the successful incorporation of all bacterial species tested, from the smallest $(0.74 \mu \mathrm{m}$; Lactococcus lactis) to the largest (10.82 $\mu \mathrm{m}$; Lactobacillus delbrueckii ssp. bulgaricus), into poly(ethylene oxide) nanofibers with an average diameter of $~ 100 \mathrm{~nm}$. All of these lactobacilli were viable after incorporation into nanofibers, with 0 to $3 \log \mathrm{CFU} / \mathrm{mg}$ loss in viability, depending on the species. Viability correlated with the hydrophobicity and extreme length of lactic acid bacteria, whereas a horizonal or vertical electrospinning set-up did not have any role. Therefore, electrospinning represents a promising method for the incorporation of lactic acid bacteria into solid delivery systems, while drying the bacterial dispersion at the same time.
\end{abstract}

Keywords: nanotechnology; biotechnology; probiotics; Lactobacillus; Lactococcus; electrospinning; nanofibers; drying; local delivery; viability

\section{Introduction}

Probiotics are living microbes that have beneficial health effects when administered to a host in a sufficient quantity. They most often belong to the very diverse genus of Lactobacillus, which includes a large number of species with a "generally recognized as safe" or "qualified presumption of safety" status [1,2]. In 2015, 175 genomes of lactobacilli were included in a comparative taxonomic study [2]. These are non-spore-forming rods or coccobacilli that are characterized by low genomic guanine and cytosine contents, the production of lactic acid, and complex nutritional requirements. They are aero-tolerant or anaerobic, aciduric, or acidophilic [1]. Lactobacillus spp. are particularly important in human nutrition and are also considered to be important cell factories in biotechnology, for the production of valuable chemicals. They have also been tested in several clinical trials to evaluate their efficiency for the treatment of a wide spectrum of diseases [1,3].

Lactobacillus probiotics are usually administered orally for the treatment of intestinal diseases, such as acute gastroenteritis [4], necrotizing enterocolitis [5], antibiotic-associated diarrhea [6], and 
inflammatory bowel disease [7], among others. Moreover, these probiotics have also shown promising potential for the treatment of extra-intestinal diseases, including urinary tract infections, periodontal disease, and bacterial vaginosis [8,9]. However, for such diseases, topical administration of the lactobacilli would appear advisable, to promote their higher efficiency.

For example, the vagina is densely colonized by microbiota $\left(10^{7}-10^{8}\right.$ colony-forming units [CFU]/g vaginal fluid) [10,11]. Among the distinct ecological environments of the human body, the vaginal microbiota is the least diverse [12], where bacteria from the genus Lactobacillus predominate in the majority of healthy women (> 70\%) [10,11]. A healthy vaginal microbiota includes from four to 12 different species [13], and the species that dominate individual microbiota include Lactobacillus crispatus, Lactobacillus jensenii, Lactobacillus gasseri, and Lactobacillus iners [11,14]. Their use for re-establishing the dominance of lactobacilli in vaginal dysbiosis (e.g., bacterial vaginosis and vaginal candidiasis) is therefore rational, and might even be the most justified among the different applications of these probiotics.

For successful treatments, probiotics need to be incorporated into patient-friendly delivery systems with large numbers of incorporated probiotics, which need to remain stable and survive for prolonged periods during storage [8]. Liquid and semi-solid dosage forms (e.g., hydrogels [15,16]) can have shorter residence times at the local site [10] and issues regarding probiotic stability compared to solid dosage forms. For preparations of these forms, different encapsulation and drying techniques have been used, including microencapsulation, emulsification, coacervation, spray drying, and lyophilization [17,18]. The main drawbacks of these techniques are the use of organic solvents and high temperatures [17]. Electrospinning represents a promising method for the incorporation of probiotics into nanofibers, allowing drying of the bacteria and preparation of a solid delivery system in a single step [19], and thereby offering considerable advantages over techniques such as microencapsulation and lyophilization.

Electrospinning is an established technique used to produce fibers with small diameters, in the range of several nanometers to micrometers, which are often called nanofibers. The manufacturing process is based on the drying of a thin liquid jet that is formed from a drop of polymer solution in a strong electric field [20]. The use of nanofibers has been suggested for several biomedical applications, including wound dressing, drug delivery, and tissue engineering [20]. Of these, drug delivery is the most promising, whereby its advantages include high drug loading, a high incorporation efficiency, the simultaneous delivery of diverse therapeutics, an increased surface area, a good mechanical resistance, an enhanced distribution at mucosal surfaces, ease of operation, and cost effectiveness [20-22].

To date, there have only been a few studies on the electrospinning of probiotics [23-28]. Bifidobacterium animalis subsp. lactis Bb12 has been incorporated into poly(vinyl alcohol) nanofibers [24]. Among the lactobacilli, Lactobacillus acidophilus was incorporated into poly(vinyl alcohol) and poly(vinyl pyrrolidone) nanofibers [25], and into agrowaste-based nanofibers [23]. Lb. gasseri was incorporated into poly(vinyl alcohol) nanofibers [28] and Lb. rhamnosus into poly(vinyl alcohol) and sodium alginate-based nanofibers [27]. Recently, we optimized the incorporation of Lactobacillus plantarum into poly(ethylene oxide) (PEO) nanofibers, and confirmed that their viability can be improved by the addition of lyoprotectants, such as trehalose [26].

Lactobacilli-containing nanofibers represent an innovative delivery system that would be particularly appropriate for topical administration. Due to scarce data on the influence of electrospinning on the viability of different Lactobacillus species, in the present study, we incorporated nine different species from the genus Lactobacillus and one from the genus Lactococcus into PEO nanofibers and assessed their viabilities following their incorporation, as a single study. To explain the higher susceptibilities of some strains to electrospinning, the morphology, zeta potential, hydrophobicity, average mass of bacterial cells, and growth characteristics of these 10 strains were also characterized.

\section{Materials and Methods}

\subsection{Materials}

Poly(ethylene oxide) (Mw, $900 \mathrm{kDa})$ and chloramphenicol were obtained from Sigma Aldrich (Steinheim, Germany). Phosphate-buffered saline (pH 7.4; osmolality: 280-315 mOsm/kg) was sourced 
from Gibco (Life Technologies, Carlsbad, CA, USA). De Man, Rogosa and Sharpe (MRS) and M-17 media for culturing the Lactobacillus spp. and L. lactis, respectively, were obtained from Merck (Darmstadt, Germany). Water, buffers, and growth media were sterilized by autoclaving at 2 bar and $121^{\circ} \mathrm{C}$ for $20 \mathrm{~min}$.

\subsection{Bacterial Strains and Culturing Conditions}

The Lactobacillus strains were grown at $37^{\circ} \mathrm{C}$ in MRS medium without aeration. L. lactis MG1363 was grown at $30{ }^{\circ} \mathrm{C}$ in $\mathrm{M}-17$ medium supplemented with $0.5 \%$ glucose (GM-17), without aeration (Table 1). For long-term storage, the bacterial strains were kept frozen at $-80{ }^{\circ} \mathrm{C}$ in their corresponding growth medium with $20 \%(v / v)$ glycerol. For each experiment, fresh bacteria cultures were cultivated. Frozen cultures were first transferred onto an appropriate growth medium agar plate and incubated for 2 days at $37^{\circ} \mathrm{C}$ (Lactobacillus spp.) or $30^{\circ} \mathrm{C}$ (L. lactis). A single bacteria colony was picked, inoculated into $10 \mathrm{~mL}$ of the appropriate medium, and incubated at $37^{\circ} \mathrm{C}$ or $30^{\circ} \mathrm{C}$ for $24 \mathrm{~h}$. Overnight cultures were diluted in fresh medium $(1: 100, v / v)$ and grown until a stationary growth phase was reached (as determined from the growth curves; see below). The cultures were centrifuged at $5000 \times g$ for $10 \mathrm{~min}$ (Sorvall Lynx 4000; ThermoFisher Scientific, Waltham, MA, USA). The cells were then washed twice with phosphate-buffered saline and resuspended in an appropriate volume of water.

Table 1. Bacterial strains used in this study, and some of their properties.

\begin{tabular}{|c|c|c|c|c|}
\hline Strain & Source & Fermentation Type & Genome Size [bp] & Reference \\
\hline \multicolumn{5}{|l|}{ Lactobacillus sp. } \\
\hline Lb. acidophilus ATCC 4356 & Infant feces & Homofermentative & 1956.699 & [29] \\
\hline Lb. delbrueckii ssp. bulgaricus ATCC 11842 & Yoghurt & Homofermentative & 1864.998 & [30] \\
\hline Lb. casei ATCC 393 & Cheese & Facultative heterofermentative & 2924.929 & [31] \\
\hline Lb. gasseri ATCC 33323 & Human isolate & Homofermentative & 1894.360 & [32] \\
\hline Lb. paracasei ATCC 25302 & Milk product & Facultative heterofermentative & 2991.737 & NCBI \\
\hline Lb. plantarum ATCC 8014 & $\mathrm{n} / \mathrm{a}$ & Facultative heterofermentative & 3254.764 & NCBI \\
\hline Lb. reuteri ATCC 55730 & Breast milk & Heterofermentative & 2036.000 & [33] \\
\hline Lb. rhamnosus ATCC 53103 & Human intestine & Homofermentative & 3005.051 & [34] \\
\hline Lb. salivarius ATCC 11741 & Infant feces & Homofermentative & 1956.699 & NCBI \\
\hline \multicolumn{5}{|l|}{ Lactococcus sp. } \\
\hline Lactococcus lactis ssp. cremoris MG1363 & Cheese & Homofermentative & 2529.478 & [35] \\
\hline
\end{tabular}

n/a: not available, NCBI: National Center for Biotechnology Information, ATCC: American Type Culture Collection.

\subsection{Characterization of Bacterial Strains}

\subsubsection{Determination of Cell Surface Charge of the Bacteria}

The cell-surface net charge of the bacteria (as represented by the zeta potential) was determined by laser Doppler micro-electrophoresis (Zetasizer Nano ZS; Malvern Instruments, Malvern, UK). Bacteria dispersions in $0.9 \%(\mathrm{~m} / \mathrm{v}) \mathrm{NaCl}$ with a concentration of $10.3 \mathrm{log} \mathrm{CFU} / \mathrm{mL}$ were 200 -fold diluted with deionized water, put into plastic cuvettes, and covered with the Zeta Dip Cell. The measurements of zeta potential were performed at $25^{\circ} \mathrm{C}$ using an He-Ne laser, with a wavelength of $633 \mathrm{~nm}$ and the backscatter detector at the scattering angle of $173^{\circ}$. The electrophoretic mobilities measured for the bacterial cells in the applied electric field were employed to automatically calculate their zeta potential using the Smoluchowski approximation of the Henry equation. At least three measurements were performed for each bacterial strain.

\subsubsection{Determination of Cell Surface Hydrophobicity of the Bacteria}

The hydrophobicity of the bacteria was determined according to the method of Perez et al. [36], with some modifications. Cultures of the strains were harvested in the stationary phase by centrifugation at $12,000 \times g$ for $5 \mathrm{~min}$ at $4{ }^{\circ} \mathrm{C}$, washed twice with $50 \mathrm{mM} \mathrm{K}_{2} \mathrm{HPO}_{4}(\mathrm{pH}$ 6.5) buffer, and finally resuspended 
in the same buffer. The cell suspensions were adjusted to an absorbance at $560 \mathrm{~nm}\left(\mathrm{~A}_{560}\right)$ of 0.5 . Three milliliters of bacterial suspensions was added to $0.6 \mathrm{~mL}$-hexadecane, vortexed for $120 \mathrm{~s}$, and left for $30 \mathrm{~min}$ at room temperature, to allow separation of the two phases. The aqueous phase was carefully removed and $\mathrm{A}_{560}$ was measured using a spectrophotometer (Lambda Bio+; Perkin Elmer, Weltham, MA, USA). The decrease in the absorbance of the aqueous phase was taken as the measure of the cell surface hydrophobicity $(\mathrm{H} \%)$, which was calculated as in Equation (1):

$$
\mathrm{H} \%=\left[\left(\mathrm{A}_{0}-\mathrm{A}\right) / \mathrm{A}_{0}\right] \times 100
$$

where $\mathrm{A}_{0}$ and $\mathrm{A}$ are the absorbances before and after extraction with $\mathrm{n}$-hexadecane, respectively.

\subsubsection{Determination of Mass of the Bacterial Cells}

Bacterial dispersions in water with known numbers of cells and known dispersion volumes were frozen at $-80^{\circ} \mathrm{C}$ for $24 \mathrm{~h}$, and then lyophilized (Beta 1-8K; Martin Christ, Osterode am Harz, Germany). The first drying phase $\left(\mathrm{T}_{\text {shelf }}=-5^{\circ} \mathrm{C} ; \mathrm{P}=0.63 \mathrm{mbar}\right)$ was performed for $24 \mathrm{~h}$, and the second drying phase $\left(\mathrm{T}_{\text {shelf }}=20^{\circ} \mathrm{C}\right)$ for $1 \mathrm{~h}$. The lyophilizates obtained were weighed.

\subsubsection{Growth Curves of Lactobacillus spp. and L. lactis}

Overnight cultures of Lactobacillus spp. and L. lactis MG1363 were diluted (1:100) in $200 \mu \mathrm{L}$ fresh MRS or GM-17 growth medium, respectively, in 96-well microplates. The plates were sealed with sealing film and incubated in a microplate reader (Sunrise; Tecan, Salzburg, Austria) at $37^{\circ} \mathrm{C}$ (or $30^{\circ} \mathrm{C}$ for L. lactis) for $24 \mathrm{~h}$. A $\mathrm{A}_{55}$ was measured every $2 \mathrm{~min}$. The plates were shaken for $10 \mathrm{~s}$ before each measurement. Each culture was grown in quadruplicate. The growth rates and lag phases of the growth curves were analyzed using the DMFit 3.5 software and the model of Baranyi and Roberts [37].

\subsection{Preparation of Polymer Solutions with the Bacteria}

Overnight cultures of bacteria were diluted (1:100) in $500 \mathrm{~mL}$ fresh medium and grown to an optical density at $600 \mathrm{~nm}\left(\mathrm{OD}_{600}\right)$ of 2.50 to 3.00. The cultures were centrifuged at $5000 \times g$ for $10 \mathrm{~min}$, and washed twice with phosphate-buffered saline. To obtain $4 \%$ (w/v) PEO bacterial dispersions, the cells were dispersed in an appropriate volume of deionized water. PEO was added to the bacterial dispersions with $10.6 \pm 0.8 \log \mathrm{CFU} / \mathrm{mL}$ in deionized water, and stirred at room temperature for $4 \mathrm{~h}$.

\subsection{Rheological Characterization of Polymer Solutions with the Bacteria}

Rotational and oscillatory tests of PEO solutions with the bacteria were performed using a rheometer (Physica MCR 301; Anton Paar, Graz, Austria) with a cone-plate measuring system (CP50-2; cone radius, $24.981 \mathrm{~mm}$; cone angle, $2.001^{\circ}$ ) at a constant temperature of $25.0 \pm 0.1^{\circ} \mathrm{C}$, as previously described $[27,28]$. The zero-gap was set to $0.209 \mathrm{~mm}$. The shear rate during the rotational tests ranged from $1 / \mathrm{s}$ to $100 / \mathrm{s}$, and the viscosity $(\eta)$ was calculated as $\eta=\tau_{c} / \dot{\gamma}$, where $\tau_{c}$ is the shear stress and $\dot{\gamma}$ is the shear rate. The relative viscosity was calculated as the viscosity of the PEO solutions with bacteria, divided by the viscosity of the PEO solution, at a shear rate of $1 / \mathrm{s}$. Oscillatory tests were performed at a frequency from 0.2 /s to $100 / \mathrm{s}$, and an amplitude of $1 \%$, which was within the linear viscoelastic region determined in prior amplitude-sweep experiments, to define the phase shift angle $(\delta)$. The storage $\left(G^{\prime}\right)$ and loss modulus $\left(G^{\prime \prime}\right)$ were calculated as in Equations (2) and (3), respectively:

$$
\begin{aligned}
& G^{\prime}=\left(\tau_{a} / \gamma_{a}\right) \times \cos \delta \\
& G^{\prime \prime}=\left(\tau_{a} / \gamma_{a}\right) \times \sin \delta
\end{aligned}
$$

where $\tau_{a}$ is the shear stress and $\gamma_{a}$ is the deformation. The damping factor was calculated as $\tan \delta=$ $\mathrm{G}^{\prime \prime} / \mathrm{G}^{\prime}$. 


\subsection{Preparation of Bacteria-Loaded Nanofibers by Electrospinning}

The bacterial dispersions in $4 \%(\mathrm{~m} / \mathrm{v})$ PEO solutions were transferred into a $5 \mathrm{~mL}$ syringe fitted with a metallic needle of a $1 \mathrm{~mm}$ inner diameter and located horizontally on a syringe pump (model R-99E; RazelTM, Linari Engineering, Valpiana, Italy). The electrode of a high-voltage power supply (model HVG-P60-R-EU; Linari Engineering, Valpiana, Italy) was clamped onto the metallic needle, and the collector was grounded and covered with a piece of aluminum foil. The process was set to a flow rate of $0.4 \mathrm{~mL} / \mathrm{h}$, voltage of $15 \mathrm{kV}$, and nozzle-to-collector distance of $15 \mathrm{~cm}$. Additionally, PEO solution with $\mathrm{Lb}$. delbrueckii ssp. bulgaricus was electrospun in a vertical electrospinning set-up employing the same equipment and conditions as used for the horizontal electrospinning.

\subsection{Characterization of Nanofibers Loaded with the Bacteria}

\subsubsection{Morphology of the Bacterial Cells and Nanofibers}

Three microliters of each bacterial dispersion was pipetted onto a metal stub and air dried, and the nanofiber mats were attached to metal stubs with double-sided conductive tape. The samples were not coated prior to the imaging under scanning electron microscopy (Supra 35 VP; Carl Zeiss, Oberkochen, Jena, Germany), which was operated at an acceleration voltage of $1 \mathrm{kV}$, with a secondary detector. The length and width of at least 30 randomly selected bacteria and the diameters of 50 randomly selected nanofibers (as parts not containing any bacteria) were measured using the Image $1.51 \mathrm{j} 8 \mathrm{software}$ (National Institutes of Health, Bethesda, MD, USA).

\subsubsection{Viability of the Bacteria}

The viability of the bacterial cells in the PEO solutions was determined prior to the electrospinning and after their incorporation into the nanofibers. The number of viable suspended bacteria in a known volume of bacterial dispersion was determined using the drop plate method [38]. Eight ten-fold serial dilutions of bacterial cells in PEO solutions were prepared using $50 \mathrm{mM}$ phosphate buffer at $\mathrm{pH} 7.4$, with each dilution in a final volume of $1 \mathrm{~mL}$. Ten microliters of each dilution was pipetted onto agar plates as five replicates, and after incubation, the dilution that contained 3 to 30 colonies per single drop was counted, and replicates were averaged. These data were expressed as CFU/mL and were converted into $\log \mathrm{CFU} / \mathrm{mL}$. The viability of the bacteria incorporated into the nanofibers was determined by dissolving a known mass of nanofibers in $50 \mathrm{mM}$ phosphate buffer, with a $\mathrm{pH}$ of 7.4. Bacterial diluting and counting were performed as described above; here, the data were expressed as $\mathrm{CFU} / \mathrm{mg}$ nanofibers, and were converted to $\log \mathrm{CFU} / \mathrm{mg}$. The experimental bacteria loading was compared to the theoretical bacteria loading. The theoretical bacteria loading $(\mathrm{CFU} / \mathrm{mg})$ was calculated as the number of bacterial cells in the polymer solution (CFU) per dry weight of polymer and bacterial cells, in $1 \mathrm{~mL}$ dispersion. The dry weight of PEO was assumed to be $4 \mathrm{mg}$, while the dry weight of $1 \times 10^{10}$ bacterial cells was determined as described in Section 2.3.3, and is shown in Table 2.

\subsection{Statistics}

The effects of hydrophobicity on the viability of the bacteria were analyzed by applying Mann-Whitney nonparametric tests $\left({ }^{*}, p<0.05\right)$, using the GraphPad Prism 5.00 software. All of the data are presented as means \pm standard deviation (SD).

\section{Results}

\subsection{Physical Characteristics of the Lactobacillus spp. and L. lactis}

The physical properties of the lactic acid bacteria (e.g., size, charge, and hydrophobicity) were hypothesized to affect their viability after incorporation into the nanofibers. Despite the wealth of information on lactic acid bacteria available, studies that compare physical properties and growth characteristics of multiple lactic acid bacteria are scarce; these were therefore determined in the present 
study for the selected pool of lactobacilli and L. lactis (Table 2, Figure 1). The lactobacilli differed little in terms of their average cell width. Two species had average cell lengths $>2 \mu \mathrm{m}$, namely Lb. gasseri $(4.68 \mu \mathrm{m})$ and $L b$. delbrueckii ssp. bulgaricus $(10.82 \mu \mathrm{m})$. The zeta potentials of the different species were comparable, at around $-10 \mathrm{mV}$. The exceptions here were Lactobacillus casei and Lactobacillus rhamnosus, with zeta potentials of $\sim 0 \mathrm{mV}$, and Lactobacillus paracasei, with the lowest zeta potential $(-23.9 \mathrm{mV})$. There were considerable differences in the cell hydrophobicities, allowing division of the bacterial species into two groups: bacteria with a lower hydrophobicity ( $<40 \%$; hydrophilic) and bacteria with a higher hydrophobicity ( $>70 \%$; hydrophobic). Differences in mass (dry weight) of the bacteria might be attributed to the production of exopolysaccharides that differ among these different species. Exopolysaccharides can remain attached to bacteria, despite the washing step. The highest mass was determined for Lb. rhamnosus ATCC 53103 and Lb. delbrueckii ssp. bulgaricus ATCC 11842, which are known producers of exopolysaccharides [39,40].

Table 2. Selected physical characteristics of the bacterial species used in this study.

\begin{tabular}{lccccc}
\hline \multicolumn{1}{c}{ Bacteria Species } & $\begin{array}{c}\text { Average Cell } \\
\text { Width }[\boldsymbol{\mu m}]\end{array}$ & $\begin{array}{c}\text { Average Cell } \\
\text { Length }[\boldsymbol{\mu m}]\end{array}$ & $\begin{array}{c}\text { Zeta Potential } \\
{[\mathbf{m}]}\end{array}$ & $\begin{array}{c}\text { Hydrophobicity } \\
{[\%]}\end{array}$ & $\begin{array}{c}\text { Mass of 1 } \times \text { 10 } \\
\text { Bacterial Cells }[\mathbf{m g}]\end{array}$ \\
\hline Lb. acidophilus & $0.56 \pm 0.04$ & $1.28 \pm 0.26$ & $-9.1 \pm 5.0$ & $78.6 \pm 1.0$ & 0.65 \\
\hline Lb. delbrueckii ssp. bulgaricus & $0.51 \pm 0.07$ & $10.82 \pm 3.31$ & $-9.4 \pm 5.5$ & $28.5 \pm 3.9$ & 9.14 \\
\hline Lb. casei & $0.58 \pm 0.06$ & $1.54 \pm 0.36$ & $-0.4 \pm 5.5$ & $11.3 \pm 0.5$ & 4.22 \\
\hline Lb. gasseri & $0.65 \pm 0.07$ & $4.68 \pm 1.43$ & $-7.9 \pm 4.6$ & $92.5 \pm 2.1$ & 5.59 \\
\hline Lb. paracasei & $0.68 \pm 0.09$ & $2.05 \pm 0.49$ & $-23.9 \pm 4.4$ & $36.4 \pm 4.8$ & 2.13 \\
\hline Lb. plantarum & $0.52 \pm 0.04$ & $1.33 \pm 0.29$ & $-12.7 \pm 4.0$ & $74.2 \pm 2.3$ & 0.54 \\
\hline Lb. reuteri & $0.72 \pm 0.08$ & $1.43 \pm 0.37$ & $-13.7 \pm 5.7$ & $71.9 \pm 5.8$ & 1.04 \\
\hline Lb. rhamnosus & $0.64 \pm 0.08$ & $2.16 \pm 0.51$ & $-3.9 \pm 4.4$ & $31.5 \pm 7.7$ & 16.31 \\
\hline Lb. salivarius & $0.70 \pm 0.07$ & $1.39 \pm 0.31$ & $-11.7 \pm 4.6$ & $90.1 \pm 1.3$ & \\
\hline L. lactis & $0.53 \pm 0.05$ & $0.74 \pm 0.18$ & $-12.8 \pm 5.5$ & $24.2 \pm 6.3$ & 1.92 \\
\hline
\end{tabular}

\subsection{Growth Characteristics of the Lactobacillus spp. and L. lactis}

Apart from their physical properties, the bacteria also differed in their growth characteristics when cultured under the same conditions (Figure 1). Lactobacillus salivarius was the fastest growing Lactobacillus spp., with a growth rate of $\sim 0.3 / \mathrm{h}$. Lb. plantarum and Lactobacillus reuteri had a growth rate of $\sim 0.2 / \mathrm{h}$, while the majority of strains grew at growth rates of $0.1 / \mathrm{h}$ to $0.2 / \mathrm{h}$. The slowest growers were $L b$. delbrueckii ssp. bulgaricus and $L b$. casei, with growth rates just above $0.05 / \mathrm{h}$. These last two and $L b$. paracasei also had the longest lag times $(>5 \mathrm{~h})$, while the rest of the bacteria had lag times of $<3 \mathrm{~h}$.

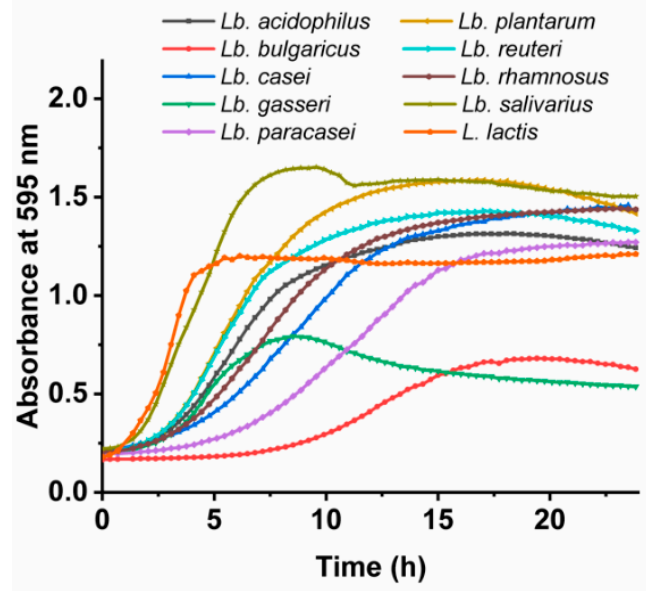

Figure 1. Representative growth curves of the Lactobacillus spp. and L. lactis. 


\subsection{Viscosity of Polymer Solutions with the Dispersed Bacteria}

The dispersions of the bacteria in $4 \%(\mathrm{~m} / \mathrm{v})$ PEO solution increased the viscosity in comparison to $4 \%(\mathrm{~m} / \mathrm{v})$ PEO solution without the bacteria (Figure 2$)$. The viscosity at the low shear rate $(1 / \mathrm{s})$ of the PEO solution was 1.36 Pas. PEO solutions with $L b$. rhamnosus and Lb. salivarius had the highest viscosities, with 2.8-fold and 2.5-fold increases, respectively, compared to the PEO solution without these bacteria. Conversely, $L b$. casei and $L b$. plantarum had the lowest viscosities among these bacterial dispersions, with only a 1.3-fold increase (Figure 2a). The PEO solutions and all of the PEO solutions with dispersed bacteria showed shear-thinning behavior, which was similar for all of the samples tested, with the exception of the PEO solution with $L b$. rhamnosus, where the viscosity decreased more rapidly through an increase in the shear rate (Figure $2 b$ ). For all of the dispersions tested, the loss modulus dominated over the storage modulus (Figure 2c), and consequently, the damping factor $(\tan \delta)$, as the ratio between the loss and storage modulus was $>1$ at all of the tested angular frequencies (Figure 2d). Therefore, in these viscoelastic dispersions, the viscous portion prevailed over the elastic one. All of these dispersions were comparable, with the exception of the PEO solution with $L b$. rhamnosus, where the storage modulus was a lot higher (Figure 2c) and the damping factor was lower (Figure 2d). This might be attributed to the production of exopolysaccharides and the pronounced growth of $L b$. rhamnosus as chains, as seen in Figure 3. Viscosity did not correlate with zeta potential or bacterial hydrophobicity.
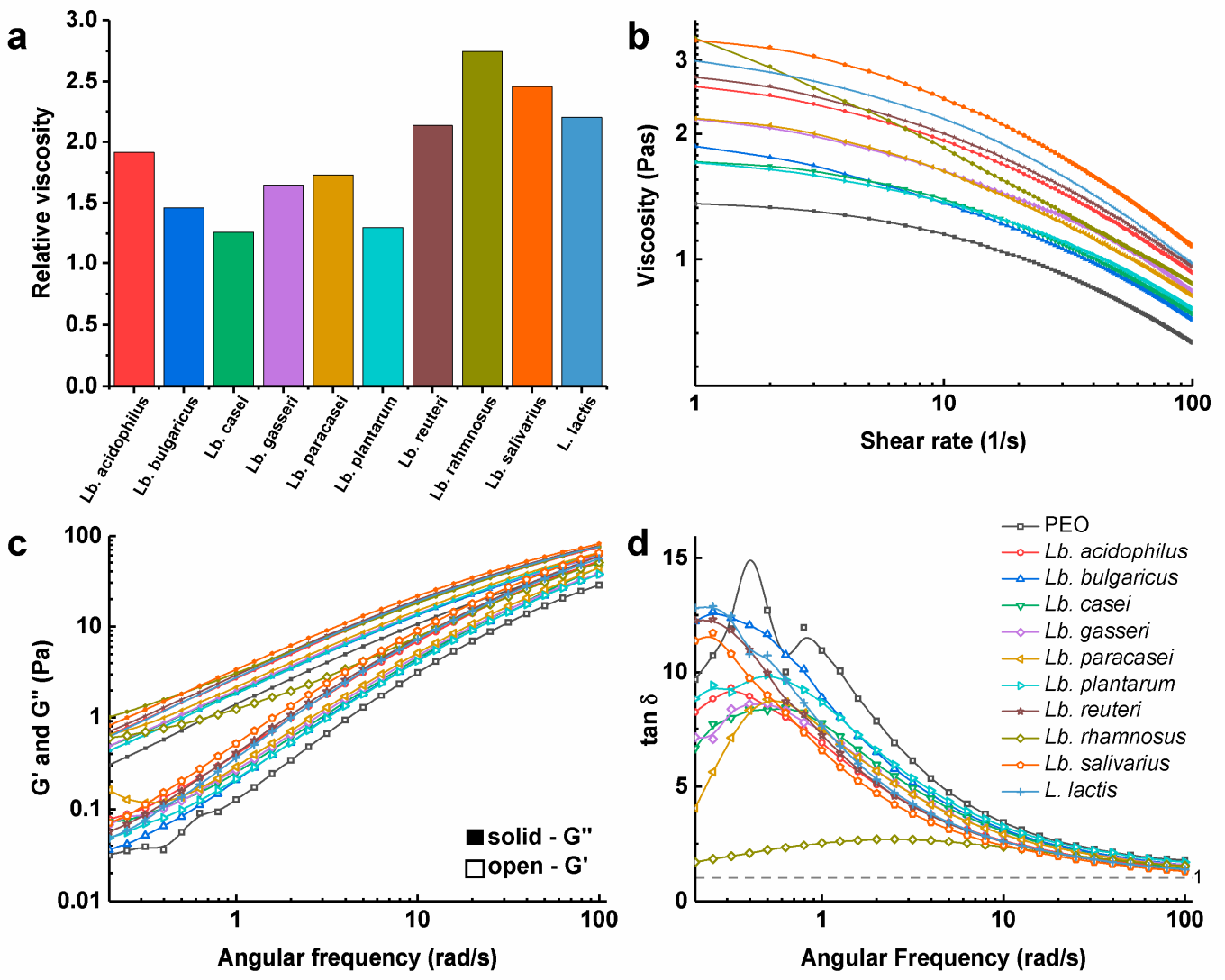

Figure 2. Rheological characterization of $4 \%(\mathrm{~m} / \mathrm{v})$ poly(ethylene oxide) (PEO) solutions without bacteria and with the dispersed Lactobacillus spp. or L. lactis. (a) Relative viscosity, as the ratio of the viscosity of the PEO dispersions with bacteria to that of the PEO solution, at a $1 / \mathrm{s}$ shear rate. (b) Viscosity of the dispersions as a function of the shear rate. (c) Storage $\left(G^{\prime}\right)$ and loss $\left(G^{\prime \prime}\right)$ moduli, and (d) $\tan \delta$ as a function of the angular frequency. 

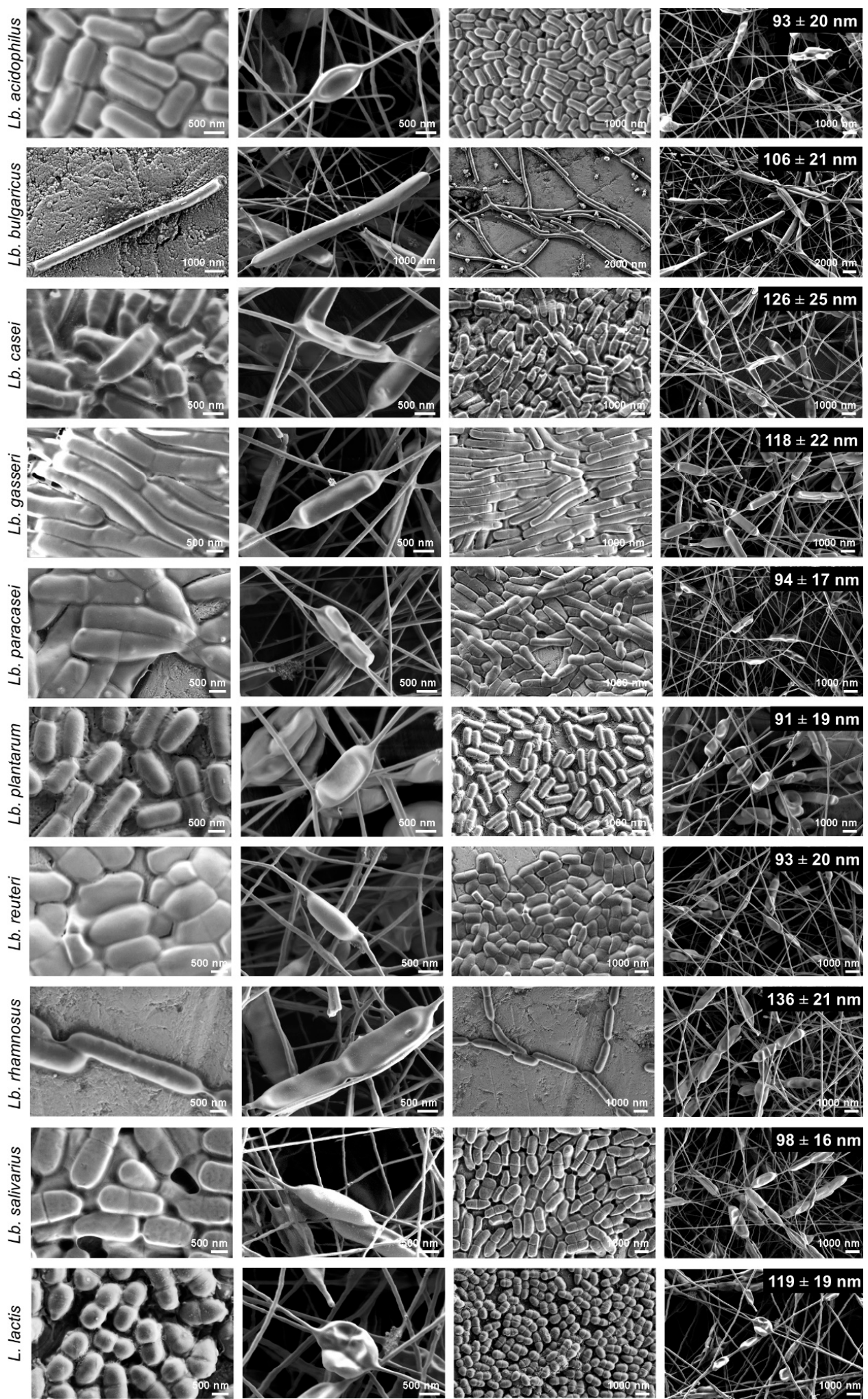

Figure 3. Scanning electron microscopy images of the lactic acid bacteria air dried from the water dispersion (columns 1, 3; under high and low magnification, respectively) and bacteria-loaded nanofibers (columns 2, 4; under high and low magnification, respectively). The numbers given in column 4 indicate the average nanofiber diameters. 


\subsection{Morphology of Nanofibers with the Bacteria}

Under scanning electron microscopy, the thin nanofibers with a thickness of $\sim 100 \mathrm{~nm}$ showed local thickenings in the shape of the bacteria, which confirmed the effective incorporation of all of these bacterial species into nanofibers (Figure 3). During SEM analysis, we did not observe any bacteria, which were not incorporated into nanofibers. The nanofiber polymer coating of the bacterial cells was thin, homogenous, and showed no cracks. Single or dividing cells were oriented along the nanofibers and evenly distributed over the nanofiber mats. These mostly retained their shape, compared to the bacteria before the incorporation; however, in some cases, the flattening of cells was seen (Figure 3). The diameters of the nanofibers with the incorporated bacteria in regions without the bacteria varied slightly among these different strains (Table 3). However, these differences did not correlate with the viscosities of the bacterial/PEO dispersions.

Table 3. Growth rates and lag times of the Lactobacillus spp. and L. lactis determined from their growth curves.

\begin{tabular}{lcc}
\hline \multicolumn{1}{c}{ Bacterial Species } & Growth Rate $[\mathbf{h}]$ & Lag Time $[\mathbf{h}]$ \\
\hline Lb. acidophilus & $0.158 \pm 0.005$ & $2.31 \pm 0.09$ \\
\hline Lb. bulgaricus & $0.066 \pm 0.001$ & $8.14 \pm 0.15$ \\
\hline Lb. casei & $0.116 \pm 0.002$ & $3.41 \pm 0.07$ \\
\hline Lb. gasseri & $0.118 \pm 0.004$ & $1.60 \pm 0.15$ \\
\hline Lb. paracasei & $0.102 \pm 0.010$ & $5.50 \pm 0.23$ \\
\hline Lb. plantarum & $0.199 \pm 0.002$ & $2.52 \pm 0.21$ \\
\hline Lb. reuteri & $0.193 \pm 0.009$ & $1.82 \pm 0.51$ \\
\hline Lb. rhamnosus & $0.125 \pm 0.001$ & $1.92 \pm 0.34$ \\
\hline Lb. salivarius & $0.297 \pm 0.028$ & $1.11 \pm 0.08$ \\
\hline L. lactis & $0.326 \pm 0.013$ & $0.84 \pm 0.07$ \\
\hline
\end{tabular}

\subsection{Viability of the Different Lactic Acid Bacteria after Electrospinning}

All of the bacterial species were viable following their incorporation into the nanofibers. For five species ( $L b$. acidophilus, $L b$. gasseri, $L b$. reuteri, Lb. salivarius, and L. lactis), the survival decreased by $<1 \log$ unit, indicating a high viability. Four species (Lb. casei, Lb. paracasei, Lb. plantarum, and Lb. rhamnosus) showed a decreased survival of between 1 and $2 \log$ units. The worst survival was for $L b$. delbrueckii ssp. bulgaricus, with more than a $2 \log$ decrease in viability (Table 4).

Table 4. Viability of the lactic acid bacteria in PEO solution before and after their incorporation into nanofibers.

\begin{tabular}{lccc}
\hline \multicolumn{1}{c}{ Bacterial Species } & $\begin{array}{c}\text { Theoretical Bacteria } \\
\text { Loading }(\boldsymbol{l o g} \text { CFU/mg) }\end{array}$ & $\begin{array}{c}\text { Experimental Bacteria } \\
\text { Loading }(\log \text { CFU/mg) }\end{array}$ & $\begin{array}{c}\text { Decrease in Viability } \\
\text { (log CFU/mg) }\end{array}$ \\
\hline Lb. acidophilus & $9.89 \pm 0.18$ & $9.18 \pm 0.21$ & 0.71 \\
Lb. bulgaricus & $8.74 \pm 0.15$ & $5.91 \pm 0.15$ & 2.83 \\
Lb. casei & $8.85 \pm 0.21$ & $7.33 \pm 0.19$ & 1.52 \\
Lb. gasseri & $9.30 \pm 0.18$ & $9.20 \pm 0.11$ & 0.09 \\
Lb. paracasei & $9.53 \pm 0.12$ & $8.02 \pm 0.18$ & 1.51 \\
Lb. plantarum & $9.99 \pm 0.06$ & $8.70 \pm 0.38$ & 1.29 \\
Lb. reuteri & $9.76 \pm 0.13$ & $9.32 \pm 0.04$ & 0.44 \\
Lb. rhamnosus & $8.55 \pm 0.13$ & $7.41 \pm 0.16$ & 1.14 \\
Lb. salivarius & $9.21 \pm 0.06$ & $6.75 \pm 0.07$ & 0.73 \\
L. lactis & $9.06 \pm 0.14$ & $8.19 \pm 0.33$ & 0.87 \\
\hline
\end{tabular}


Interestingly, the loss of viability correlated with the hydrophobicity of the bacterial cells. The hydrophilic bacteria showed significantly higher decreases in viability than the hydrophobic bacteria (Figure 4). This suggests that hydrophobic molecules at the bacterial surface (e.g., including exopolysaccharides) offer better protection for the bacteria during their incorporation into nanofibers. There were no correlations between the loss of viability and viscosity of dispersion or zeta potential of cells.

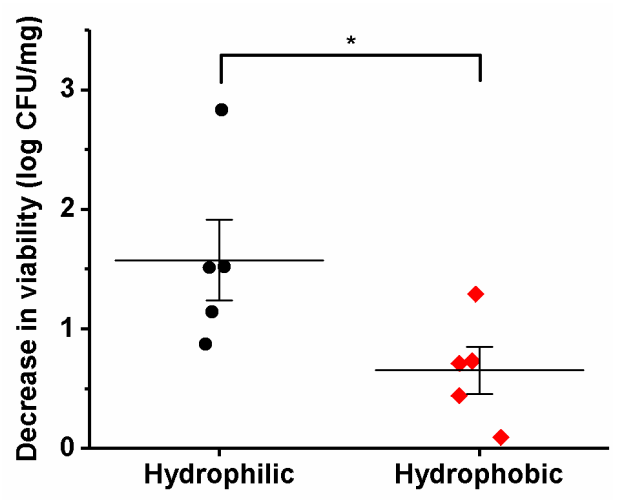

Figure 4. Bacterial cells with a lower hydrophobicity ( $<40 \%$, hydrophilic, black circles) showed larger decreases in viability after incorporation into nanofibers, in comparison to bacterial cells with a higher hydrophobicity ( $>70 \%$, hydrophobic, red diamonds). The horizontal lines indicate the means. ${ }^{*}, p<$ 0.05 (Mann-Whitney tests).

In general, the width or length of the cells did not correlate with the viability of the bacteria. However, for Lb. delbrueckii ssp. bulgaricus in particular, the loss of viability might also be correlated with the bacterial cell size, as these bacteria had by far the longest cells and by far the highest decrease in viability. To exclude any influence of the direction of the electrospinning and possible losses of bacteria during the electrospinning due to the gravitational force, horizontal electrospinning was replaced with vertical electrospinning. The survivals here were not significantly different (Figure 5), which suggests that the direction of electrospinning has no major role in the bacterial viability.

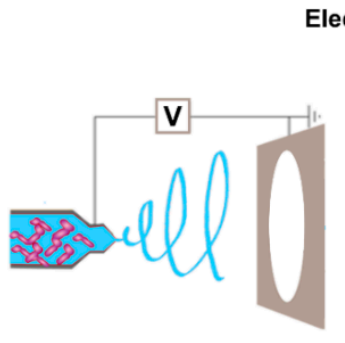

horizontal
Electrospinning

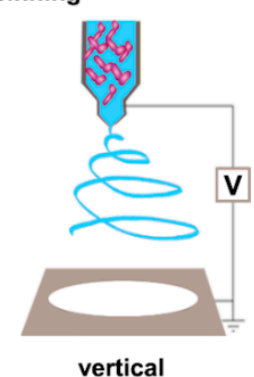

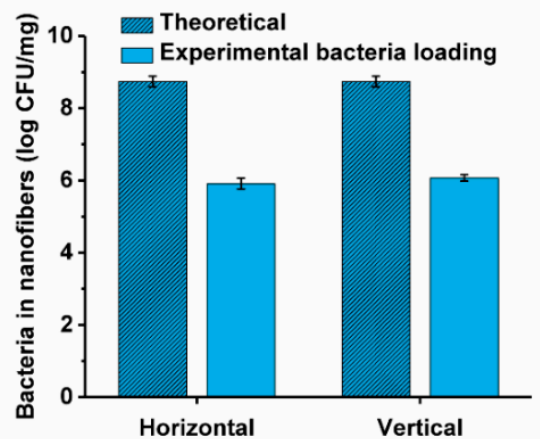

Figure 5. Theoretical and experimental loading of Lb. delbrueckii ssp. bulgaricus in nanofibers using either horizontal or vertical electrospinning.

\section{Discussion}

The scope of the use of probiotics can be widened by the introduction of novel delivery systems. The incorporation of probiotics into nanofibers is an emerging approach for the delivery of probiotics to body sites that require their controlled and/or sustained release. We and others have recently demonstrated the effective incorporation of lactic acid bacteria into nanofibers, and have shown that these incorporated bacteria retain their viability. However, previous studies have been limited to just five species of lactic acid bacteria: Lb. acidophilus, Lb. gasseri Lb. plantarum, Lb. rhamnosus, and Bifidobacterium animalis [19,23-28]. Different species of lactic acid bacteria can differ considerably in 
their properties and therapeutic effects, and therefore, it is crucial to strengthen our knowledge of the behavior of the different lactic acid bacteria during electrospinning.

We effectively incorporated nine taxonomically different species of the genus Lactobacillus and one species of the genus Lactococcus into PEO nanofibers, and have thus considerably increased our knowledge of the number of lactic acid bacteria that can be delivered using electrospun nanofibers. The dispersions of these bacteria in $4 \%(\mathrm{~m} / \mathrm{v})$ PEO solution had different rheological properties. A higher viscosity was attributed to the production of exopolysaccharides or to the pronounced chain growth phenotype. Although the bacteria in the PEO solution affected the viscosity, there was no need to change the process parameters during the electrospinning of the previously optimized electrospinning of PEO solutions without the bacteria, which enabled the production of smooth PEO nanofibers in a continuous process [26]. The previously reported mean diameter of PEO nanofibers without the incorporated bacteria was $135 \pm 25 \mathrm{~nm}$ [26], which was similar to Lb. rhamnosus-loaded nanofibers here, whereas the other nanofibes were a little smaller, with the lowest mean diameter of $91 \pm 19 \mathrm{~nm}$ for $\mathrm{Lb}$. plantarum-loaded nanofibers. In line with previous studies, the addition of the bacteria to the PEO solutions did not only changed the viscosity, but also the dispersion conductivity. A prominent influence of conductivity over viscosity might lead to the decreased nanofiber diameters seen for the bacteria-loaded nanofibers $[19,26]$.

While observing the bacteria-loaded nanofibers using scanning electron microscopy, we could clearly distinguish incorporated cells in nanofibers. Thus, electrospinning provided complete incorporation of the bacteria, even for the strain with the largest cells among those studied here (i.e., Lb. delbrueckii ssp. bulgaricus; cell length, $10.82 \mu \mathrm{m}$ ). As observed previously [26], although the morphology of the bacterial cells in the nanofibers was similar to their morphology obtained after air-drying the bacterial dispersions, some of the cells were flattened due to their drying and dehydration, or to the mechanical stress they had undergone [41].

All of these species of lactic acid bacteria that were incorporated survived the electrospinning; however, the theoretical and experimental bacterial loading differed. The electrospinning process results in a high incorporation efficiency of drugs [42] or bacteria [19] and here, the difference between both loadings was probably due to the decrease of bacterial viability. There were no correlations between the growth characteristics, viscosity of the dispersion, or zeta potential of the lactic acid bacteria and their survival. On the other hand, the decrease in viability of the bacteria in the nanofibers correlated with the hydrophobicities of the cells. Hydrophobicity depends on the surface structures of the bacterial cells, such as lipoteichoic acid, S-layer proteins, outer membrane proteins and lipids, surface fibrils, and various fimbriae or core oligosaccharides [43]. Considerable differences among the surface properties of lactic acid bacteria were also seen in our previous study [44]. We hypothesize that the hydrophobic surface offers better protection from the hydrophilic solution in which the bacteria are dispersed.

Another possible predictor of bacterial viability in these nanofibers is their extreme morphology. Lb. delbrueckii ssp. bulgaricus had by far the largest cells and the lowest viability, as the only species with a $>2 \log$ unit decrease in viability. This might be a consequence of the large bacteria surface per cell. The viability was not affected by the direction of electrospinning, which thus excluded gravitational effects.

To summarize, while the electrospinning process is feasible regardless of the species of lactic acid bacteria used, the prediction of viability is challenging and will require the testing of individual strains.

\section{Conclusions}

In the present study, we incorporated a range of safe lactic acid bacteria into PEO-based nanofibers, several of which are confirmed probiotics. All of the lactic acid bacteria remained viable after their incorporation into the nanofibers using an electrospinning procedure appropriate for PEO solutions, without the need for additional optimization. However, the survival of these lactic acid bacteria differed across two log units, and despite the determination of the physical and growth characteristics and the viscosities of the bacterial dispersions, no clear relationships were seen between the survival 
and the parameters measured. This suggests that the prediction of bacterial survival during the electrospinning process is challenging, and that the formulation of each particular bacterial strain will need to be optimized separately. The exceptions are the cell hydrophobicity and the extreme morphological characteristics of the bacteria (e.g., greatest size for Lb. delbrueckii ssp. bulgaricus), which offer some indications in terms of bacterial survival after their incorporation into nanofibers. The developed nanofiber-based delivery systems could be useful for the delivery of lactic acid bacteria to mucosal surfaces, such as oral, nasal, or vaginal surfaces.

Author Contributions: Conceptualization, methodology, investigation, K.Š. and Š.Z.; writing—original draft preparation, A.B., K.Š. and Š.Z.; writing-review and editing, A.B., J.K., K.S.., P.K. and Š.Z.; visualization, A.B. and Š.Z.; supervision, project administration, resources, funding acquisition, A.B. and J.K.

Funding: This research was funded by the Slovenian Research Agency, grant numbers P4-0127, P1-0189 and J1-9194. Acknowledgments: We thank Christopher Berrie for critical reading of the manuscript.

Conflicts of Interest: The authors declare that they have no conflict of interest. The funders had no role in the design of the study; in the collection, analyses, or interpretation of data; in the writing of the manuscript; or in the decision to publish the results.

\section{References}

1. Salvetti, E.; Torriani, S.; Felis, G.E. The Genus Lactobacillus: A Taxonomic Update. Probiotics Antimicrob. Proteins 2012, 4, 217-226. [CrossRef] [PubMed]

2. Sun, Z.; Harris, H.M.; McCann, A.; Guo, C.; Argimon, S.; Zhang, W.; Yang, X.; Jeffery, I.B.; Cooney, J.C.; Kagawa, T.F.; et al. Expanding the biotechnology potential of lactobacilli through comparative genomics of 213 strains and associated genera. Nat. Commun. 2015, 6, 8322. [CrossRef] [PubMed]

3. Bosma, E.F.; Forster, J.; Nielsen, A.T. Lactobacilli and pediococci as versatile cell factories - Evaluation of strain properties and genetic tools. Biotechnol. Adv. 2017, 35, 419-442. [CrossRef] [PubMed]

4. Guarino, A.; Guandalini, S.; Lo Vecchio, A. Probiotics for Prevention and Treatment of Diarrhea. J. Clin. Gastroenterol. 2015, 49 (Suppl. 1), S37-S45. [CrossRef]

5. AlFaleh, K.; Anabrees, J. Probiotics for prevention of necrotizing enterocolitis in preterm infants. Cochrane Database Syst. Rev. 2014. [CrossRef] [PubMed]

6. Cai, J.; Zhao, C.; Du, Y.; Zhang, Y.; Zhao, M.; Zhao, Q. Comparative efficacy and tolerability of probiotics for antibiotic-associated diarrhea: Systematic review with network meta-analysis. United Eur. Gastroenterol. J. 2018, 6, 169-180. [CrossRef] [PubMed]

7. Ganji-Arjenaki, M.; Rafieian-Kopaei, M. Probiotics are a good choice in remission of inflammatory bowel diseases: A meta analysis and systematic review. J. Cell. Physiol. 2018, 233, 2091-2103. [CrossRef] [PubMed]

8. Rupa, P.; Mine, Y. Recent advances in the role of probiotics in human inflammation and gut health. J. Agric. Food Chem. 2012, 60, 8249-8256. [CrossRef] [PubMed]

9. Matsubara, V.H.; Bandara, H.M.; Ishikawa, K.H.; Mayer, M.P.; Samaranayake, L.P. The role of probiotic bacteria in managing periodontal disease: A systematic review. Expert Rev. Anti. Infect. Ther. 2016, 14, 643-655. [CrossRef]

10. Borges, S.; Barbosa, J.; Teixeira, P. Drug Delivery Systems for Vaginal Infections. Front. Clin. Drug Res. 2016, $2,233$.

11. Petrova, M.I.; Lievens, E.; Malik, S.; Imholz, N.; Lebeer, S. Lactobacillus species as biomarkers and agents that can promote various aspects of vaginal health. Front. Physiol. 2015, 6, 81. [CrossRef] [PubMed]

12. Belkaid, Y.; Naik, S. Compartmentalized and systemic control of tissue immunity by commensals. Nat. Immunol. 2013, 14, 646. [CrossRef] [PubMed]

13. Sycuro, L.K.; Fredricks, D.N. Microbiota of the Genitourinary Tract. The Human Microbiota: How Microbial Communities Affect. Health and Disease; John Wiley Sons: Hoboken, NJ, USA, 2013; pp. 167-210.

14. Ravel, J.; Gajer, P.; Abdo, Z.; Schneider, G.M.; Koenig, S.S.; McCulle, S.L.; Karlebach, S.; Gorle, R.; Russell, J.; Tacket, C.O.; et al. Vaginal microbiome of reproductive-age women. Proc. Natl. Acad. Sci. USA 2011, 108, 4680-4687. [CrossRef] [PubMed]

15. Gao, S.; Tang, G.; Hua, D.; Xiong, R.; Han, J.; Jiang, S.; Zhang, Q.; Huang, C. Stimuli-responsive bio-based polymeric systems and their applications. J. Mater. Chem. B 2019, 7, 709-729. [CrossRef] 
16. Ding, Q.; Xu, X.; Yue, Y.; Mei, C.; Huang, C.; Jiang, S.; Wu, Q.; Han, J. Nanocellulose-Mediated Electroconductive Self-Healing Hydrogels with High Strength, Plasticity, Viscoelasticity, Stretchability, and Biocompatibility toward Multifunctional Applications. ACS App. Mater. Inter. 2018, 10, 27987-28002. [CrossRef] [PubMed]

17. Ghorani, B.; Tucker, N. Fundamentals of electrospinning as a novel delivery vehicle for bioactive compounds in food nanotechnology. Food Hydrocolloid 2015, 51, 227-240. [CrossRef]

18. Mirtič, J.; Rijavec, T.; Zupančič, S.; Zvonar Pobirk, A.; Lapanje, A.; Kristl, J. Development of probiotic-loaded microcapsules for local delivery: Physical properties, cell release and growth. Eur. J. Pharm. Sci. 2018, 121, 178-187. [CrossRef] [PubMed]

19. Zupancčič, Š.; Rijavec, T.; Lapanje, A.; Petelin, M.; Kristl, J.; Kocbek, P. Nanofibers with Incorporated Autochthonous Bacteria as Potential Probiotics for Local Treatment of Periodontal Disease. Biomacromolecules 2018, 19, 4299-4306. [CrossRef]

20. Hu, X.; Liu, S.; Zhou, G.; Huang, Y.; Xie, Z.; Jing, X. Electrospinning of polymeric nanofibers for drug delivery applications. J. Control. Release 2014, 185, 12-21. [CrossRef]

21. Chou, S.F.; Carson, D.; Woodrow, K.A. Current strategies for sustaining drug release from electrospun nanofibers. J. Control. Release 2015, 220, 584-591. [CrossRef]

22. Zupančič, Š. Core-shell nanofibers as drug delivery systems. Acta Pharm. 2019, 69, 131-153. [CrossRef] [PubMed]

23. Fung, W.Y.; Yuen, K.H.; Liong, M.T. Agrowaste-based nanofibers as a probiotic encapsulant: Fabrication and characterization. J. Agric. Food Chem. 2011, 59, 8140-8147. [CrossRef] [PubMed]

24. Lopez-Rubio, A.; Sanchez, E.; Wilkanowicz, S.; Sanz, Y.; Lagaron, J.M. Electrospinning as a useful technique for the encapsulation of living bifidobacteria in food hydrocolloids. Food Hydrocolloid 2012, 28, 159-167. [CrossRef]

25. Nagy, Z.K.; Wagner, I.; Suhajda, A.; Tobak, T.; Harasztos, A.H.; Vigh, T.; Soti, P.L.; Pataki, H.; Molnar, K.; Marosi, G. Nanofibrous solid dosage form of living bacteria prepared by electrospinning. Express Polym. Lett. 2014, 8, 352-361. [CrossRef]

26. Skrlec, K.; Zupancic, S.; Prpar Mihevc, S.; Kocbek, P.; Kristl, J.; Berlec, A. Development of electrospun nanofibers that enable high loading and long-term viability of probiotics. Eur. J. Pharm. Biopharm. 2019, 136, 108-119. [CrossRef] [PubMed]

27. Ceylan, Z.; Meral, R.; Karakaş, C.Y.; Dertli, E.; Yilmaz, M.T. A novel strategy for probiotic bacteria: Ensuring microbial stability of fish fillets using characterized probiotic bacteria-loaded nanofibers. Innov. Food Sci. Emerg. Technol. 2018, 48, 212-218. [CrossRef]

28. Amna, T.; Hassan, M.S.; Pandeya, D.R.; Khil, M.S.; Hwang, I.H. Classy non-wovens based on animate L. gasseri-inanimate poly(vinyl alcohol): Upstream application in food engineering. Appl. Microbiol. Biotechnol. 2013, 97, 4523-4531. [CrossRef] [PubMed]

29. Palomino, M.M.; Allievi, M.C.; Fina Martin, J.; Waehner, P.M.; Prado Acosta, M.; Sanchez Rivas, C.; Ruzal, S.M. Draft Genome Sequence of the Probiotic Strain Lactobacillus acidophilus ATCC 4356. Genome Announc. 2015, 3. [CrossRef] [PubMed]

30. van de Guchte, M.; Penaud, S.; Grimaldi, C.; Barbe, V.; Bryson, K.; Nicolas, P.; Robert, C.; Oztas, S.; Mangenot, S.; Couloux, A.; et al. The complete genome sequence of Lactobacillus bulgaricus reveals extensive and ongoing reductive evolution. Proc. Natl. Acad. Sci. USA 2006, 103, 9274-9279. [CrossRef] [PubMed]

31. Toh, H.; Oshima, K.; Nakano, A.; Takahata, M.; Murakami, M.; Takaki, T.; Nishiyama, H.; Igimi, S.; Hattori, M.; Morita, H. Genomic adaptation of the Lactobacillus casei group. PLoS ONE 2013, 8, e75073. [CrossRef] [PubMed]

32. Azcarate-Peril, M.A.; Altermann, E.; Goh, Y.J.; Tallon, R.; Sanozky-Dawes, R.B.; Pfeiler, E.A.; O’Flaherty, S.; Buck, B.L.; Dobson, A.; Duong, T.; et al. Analysis of the genome sequence of Lactobacillus gasseri ATCC 33323 reveals the molecular basis of an autochthonous intestinal organism. Appl. Environ. Microbiol. 2008, 74, 4610-4625. [CrossRef] [PubMed]

33. Saulnier, D.M.; Santos, F.; Roos, S.; Mistretta, T.A.; Spinler, J.K.; Molenaar, D.; Teusink, B.; Versalovic, J. Exploring metabolic pathway reconstruction and genome-wide expression profiling in Lactobacillus reuteri to define functional probiotic features. PLoS ONE 2011, 6, e18783. [CrossRef] [PubMed] 
34. Morita, H.; Toh, H.; Oshima, K.; Murakami, M.; Taylor, T.D.; Igimi, S.; Hattori, M. Complete genome sequence of the probiotic Lactobacillus rhamnosus ATCC 53103. J. Bacteriol. 2009, 191, 7630-7631. [CrossRef] [PubMed]

35. Linares, D.M.; Kok, J.; Poolman, B. Genome sequences of Lactococcus lactis MG1363 (revised) and NZ9000 and comparative physiological studies. J. Bacteriol. 2010, 192, 5806-5812. [CrossRef] [PubMed]

36. Perez, P.F.; Minnaard, Y.; Disalvo, E.A.; De Antoni, G.L. Surface properties of bifidobacterial strains of human origin. Appl. Environ. Microbiol. 1998, 64, 21-26. [PubMed]

37. Baranyi, J.; Roberts, T.A. A dynamic approach to predicting bacterial growth in food. Int. J. Food Microbiol. 1994, 23, 277-294. [CrossRef]

38. Herigstad, B.; Hamilton, M.; Heersink, J. How to optimize the drop plate method for enumerating bacteria. J. Microbiol. Methods 2001, 44, 121-129. [CrossRef]

39. Lebeer, S.; Verhoeven, T.L.; Francius, G.; Schoofs, G.; Lambrichts, I.; Dufrene, Y.; Vanderleyden, J.; De Keersmaecker, S.C. Identification of a Gene Cluster for the Biosynthesis of a Long, Galactose-Rich Exopolysaccharide in Lactobacillus rhamnosus GG and Functional Analysis of the Priming Glycosyltransferase. Appl. Environ. Microbiol. 2009, 75, 3554-3563. [CrossRef]

40. Zeidan, A.A.; Poulsen, V.K.; Janzen, T.; Buldo, P.; Derkx, P.M.F.; Oregaard, G.; Neves, A.R. Polysaccharide production by lactic acid bacteria: From genes to industrial applications. FEMS Microbiol. Rev. 2017, 41, S168-S200. [CrossRef]

41. Reznik, S.N.; Yarin, A.L.; Zussman, E.; Bercovici, L. Evolution of a compound droplet attached to a core-shell nozzle under the action of a strong electric field. Phys. Fluids 2006, 18, 062101. [CrossRef]

42. Kajdič, S.; Vrečer, F.; Kocbek, P. Preparation of poloxamer-based nanofibers for enhanced dissolution of carvedilol. Eur. J. Pharm. Sci. 2018, 117, 331-340. [CrossRef] [PubMed]

43. Krasowska, A.; Sigler, K. How microorganisms use hydrophobicity and what does this mean for human needs? Front. Cell Infect. Microbiol. 2014, 4, 112. [CrossRef] [PubMed]

44. Zadravec, P.; Štrukelj, B.; Berlec, A. Improvement of LysM-mediated surface display of designed ankyrin repeat proteins (DARPins) in recombinant and nonrecombinant strains of Lactococcus lactis and Lactobacillus Species. Appl. Environ. Microbiol. 2015, 81, 2098-2106. [CrossRef] [PubMed]

(C) 2019 by the authors. Licensee MDPI, Basel, Switzerland. This article is an open access article distributed under the terms and conditions of the Creative Commons Attribution (CC BY) license (http://creativecommons.org/licenses/by/4.0/). 